\title{
CeDAMar global database of abyssal biological sampling
}

\author{
Carol T. Stuart ${ }^{1, *}$, Pedro Martinez Arbizu ${ }^{2}$, Craig R. Smith ${ }^{3}$, Tina Molodtsova ${ }^{4}$, \\ Angelika Brandt ${ }^{5}$, Ron J. Etter ${ }^{1}$, Elva Escobar-Briones ${ }^{6}$, Marie-Claire Fabri ${ }^{7}$, \\ Michael A. $\operatorname{Rex}^{1}$
}

\author{
${ }^{1}$ Department of Biology, University of Massachusetts, Boston, Massachusetts 02125, USA \\ ${ }^{2}$ German Centre for Biodiversity Research, DZMB Forschungsinstitut Senckenberg, Südstrand 44, 26382 Wilhelmshaven, Germany \\ ${ }^{3}$ Department of Oceanography, University of Hawaii, 1000 Pope Road, Honolulu, Hawaii 96822, USA \\ ${ }^{4}$ P.P. Shirshov Institute of Oceanology RAS, Moscow 117218, Russia \\ ${ }^{5}$ Zoological Institute and Zoological Museum, Martin-Luther-King-Platz 3, 20146 Hamburg, Germany \\ ${ }^{6}$ Universidad Nacional Autónoma de México, A. P. 70-305 Ciudad Universitaria, 04510 México City, Mexico \\ ${ }^{7}$ IFREMER, BP 70, 29280 Plouzane, France
}

\begin{abstract}
The Census of the Diversity of Abyssal Marine Life (CeDAMar), a division of the Census of Marine Life, has compiled the first comprehensive global database of biological samples taken in the abyssal plains of the world ocean. It is an essential resource for planning future exploration of the abyss, for synthesizing patterns of biogeography and biodiversity, and for environmentally safe exploitation of natural resources. The database is described in this article, and made available to investigators through the CeDAMar website.
\end{abstract}

KEY WORDS: Biodiversity $\cdot$ Deep sea $\cdot$ Database $\cdot$ Marine benthos $\cdot$ Abyssal

\section{INTRODUCTION}

The great abyssal plains of the world ocean form nearly half of the earth's surface. Frigid, dark, and remote, they remain largely unexplored. Where sampled, they are known to support a surprisingly rich fauna adapted to extreme conditions. But geographic distributions of abyssal species and large-scale patterns of biodiversity are very poorly documented. At a time when exploitation of the ocean's huge mineral resources is imminent, the impact of these activities on the abyssal environment and global biosphere cannot be accurately evaluated (Glover \& Smith 2003, Thiel 2003).

The Census of the Diversity of Abyssal Marine Life (CeDAMar) is a division of the Census of Marine Life (www.coml.org). It is a $10 \mathrm{yr}$ program dedicated to encouraging abyssal exploration and developing integrated international research efforts on abyssal biodiversity. CeDAMar now includes 8 affiliated oceano- graphic projects that operate in the Atlantic, Pacific, Indian, and Southern Oceans (www.cedamar.org). A major difficulty in assessing biodiversity, designing new initiatives, and identifying regions that had never been investigated was that no database of abyssal sampling existed. Thus, a primary objective was to develop the first global database of abyssal biological sampling as an indispensable resource for current and future research.

\section{THE DATABASE}

The sampling sites in the database are shown in Fig. 1. They include samples collected from 4000 to $6000 \mathrm{~m}$ in the Atlantic and Indo-Pacific, and $>3000 \mathrm{~m}$ in adjacent seas where abyssal plains are often shallower. The records extend in time from the HMS 'Challenger' expedition (1872-1876) to 2005. The majority of information in the database is taken from the scien- 


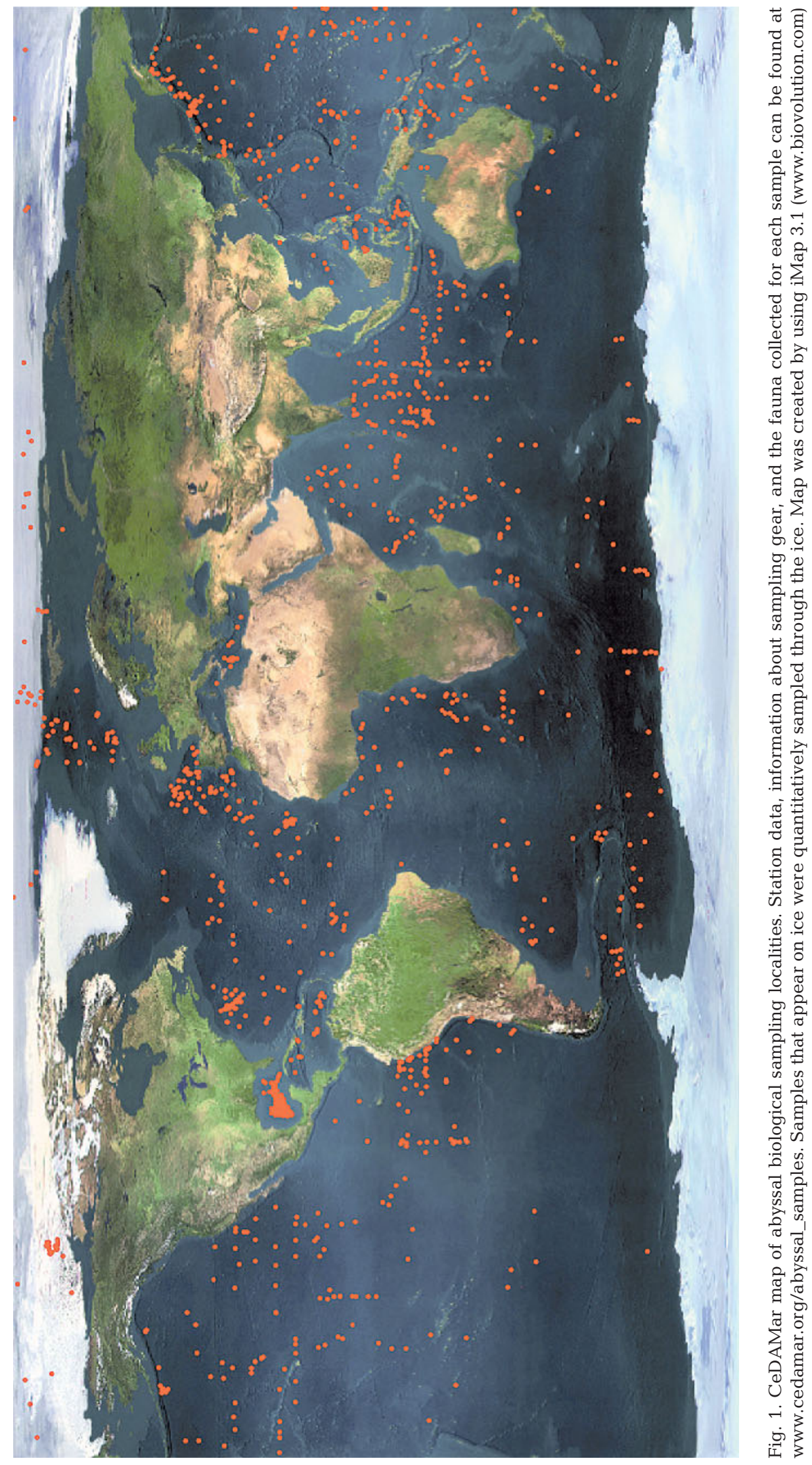




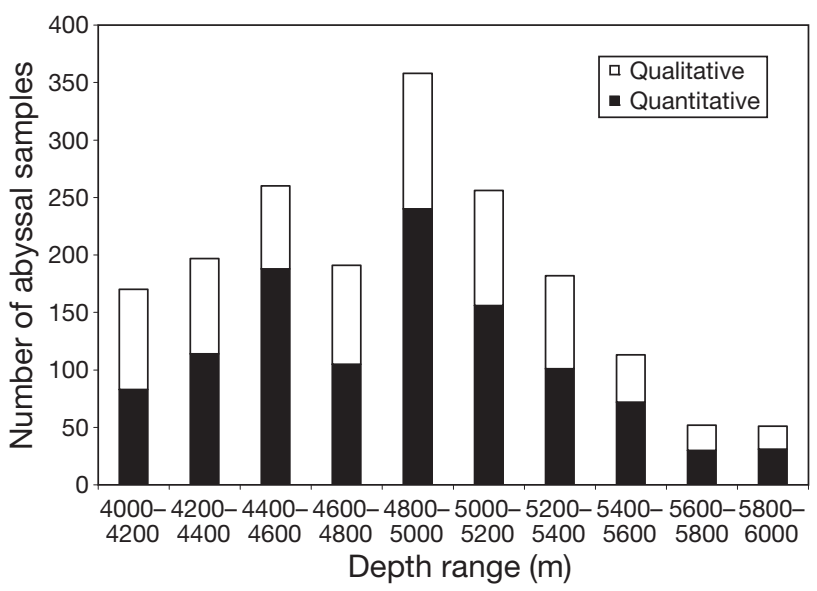

Fig. 2. Depth distribution of abyssal samples collected by quantitative and qualitative gear between 4000 and $6000 \mathrm{~m}$. The total number of samples (1830) is higher than the number of sites sampled (1600) because of replicate sampling with different gear. Deeper ( $>5400 \mathrm{~m})$ and more remote regions of the abyss are still very poorly represented

tific literature and 3 national databases from Russia, France, and Mexico. Included for each of the sampling sites are the oceanographic region, depth, latitude, longitude, sampling date, research vessel, sampling gear, station identification, faunal groups collected, location of archived material, and references to published accounts of the sampling programs. New data will be added as they become available.

The most immediate impression from the map of biological stations (Fig. 1) is just how few abyssal samples have been taken and how sparsely distributed they are. In total, there are only about 1600 documented sites: $60 \%$ for quantitative samples (grabs, box corers, and multicorers), and $40 \%$ for qualitative samples (trawls and epibenthic sleds). A minute proportion, $1.4 \times 10^{-9} \%$, of the abyssal sea floor has been sampled. The uneven distribution of sites reflects mainly the proximity to long-established American and European oceanographic institutions. There are vast areas, particularly in the Central Pacific and Southern Ocean, that remain virtually unknown. Depth coverage of abyssal samples is also very uneven (Fig. 2). The deepest and most remote areas (>5400 m) are the most

Editorial responsibility: Hans Heinrich Janssen, Oldendorf/Luhe, Germany poorly sampled. Attempting to understand abyssal biodiversity from existing data would be tantamount to characterizing terrestrial plant diversity based on 1600 random snapshots of plant life in, for example, only continents of the eastern hemisphere. Clearly, there is a very pressing need for more abyssal exploration to assess its contribution to global biodiversity.

The single biggest obstacle to compiling the database was determining the location of material acquired by past expeditions. Collections from $\sim 80 \%$ of the sampling sites have an existing or clearly intended destination in museums, but in some cases we could trace only certain taxa. This leaves a substantial amount of material unaccounted for. Continued access to these collections is vital for the basic taxonomic research needed to document abyssal biogeography and biodiversity, both for basic research and to assess the potential impact of anthropogenic disturbance. Archived material has also taken on significant added value with new technology to sequence DNA from preserved specimens and to measure climate change by using stable isotopes in carbonate skeletal structures. An important priority in future abyssal research must be to devote adequate planning and funding to ensure that the material collected is properly archived.

The abyssal map of biological sampling is available to all investigators at www.cedamar.org/abyssal_ samples. On the website, users can click on any sampling site in the map (similar to Fig. 1) to obtain available information. The bibliography of the references for the sampling sites can be reached by clicking on 'bibliography' within the text found at www.cedamar. org/Abyssal-benthic-biological-sampling. The database will enable others to build on this foundation by submitting additional existing data and data from future abyssal expeditions.

\section{LITERATURE CITED}

Glover AG, Smith CR (2003) The deep-sea floor ecosystem: current status and prospects of anthropogenic change by the year 2025. Environ Conserv 30:219-241

Thiel H (2003) Anthropogenic impacts on the deep sea. In: Tyler PA (ed) Ecosystems of the deep oceans, Vol 28. Ecosytems of the world. Elsevier, Amsterdam, p 427-470

Submitted: February 4, 2008; Accepted: September 30, 2008 Proofs received from author(s): November 17, 2008 